\title{
Decomposition of chestnut litterfall and eight-year soil chemical changes under a no-tillage management system in Northern Portugal
}

\author{
Fernando RAIMUNDO $^{1 *}$, Afonso MARTINs ${ }^{1}$, Manuel MADEIRA ${ }^{2}$ \\ ${ }^{1}$ Departamento de Edafologia, Universidade de Trás-os-Montes e Alto Douro, Ap. 1013, 5001-801 Vila Real, Portugal \\ ${ }^{2}$ Instituto Superior de Agronomia, Universidade Técnica de Lisboa, Tapada da Ajuda, 1349-017 Lisboa, Portugal
}

(Received 25 April 2007; accepted 22 January 2008)

\begin{abstract}
-
- Chestnut stands (Castanea sativa Mill.) for fruit production, in Northern Portugal, are subjected to frequent soil tillage operations, which is considered a threat for the system sustainability.

- The effects of replacement of conventional tillage by the no-tillage system in chestnut stands on decomposition and nutrient dynamics of leaf litter and burs were evaluated, using the litterbag methodology. Amounts of mass and nutrients in the organic layers, and chemical characteristics of the $0-20 \mathrm{~cm}$ top soil layer were assessed after eight years.

- The mass loss and release of N, P, Ca and Mg from both leaves and burs buried in the soil were faster than from those placed on the soil surface. Burs decomposed and released nutrients more slowly than leaf litter. The no-tillage system led to the formation of organic layers, which retained great amounts of $\mathrm{N}\left(249.2 \mathrm{~kg} \mathrm{ha}^{-1}\right)$ and $\mathrm{Ca}\left(215.5 \mathrm{~kg} \mathrm{ha}^{-1}\right)$. Such a management system increased the concentration of organic $\mathrm{C}$ and nutrients in the $0-5 \mathrm{~cm}$ top soil layer, but significant differences were only observed for exchangeable $\mathrm{Ca}$.

- The no-tillage system may enhance organic $\mathrm{C}$ accumulation regarding the conventional system, due to the increment in both organic and mineral soil layers.
\end{abstract}

litterfall decomposition / litterbag / nutrient dynamics / chestnut stand / soil management / decomposition models / no-tillage / conventional tillage

Résumé - Décomposition des chutes de litière de châtaignier et huit années de changements chimiques du sol sous un système de gestion sans labour dans le Nord du Portugal.

- Les peuplements de châtaignier (Castanea sativa Mill.) pour la production de fruits dans le Nord du Portugal font l'objet de fréquentes opérations de labour, qui sont considérées comme une menace pour un système de gestion durable.

- Les effets de remplacement du labour traditionnel par un système sans labour dans les peuplements de châtaignier sur la décomposition et la dynamique des nutriments des feuilles de la litière et des bogues, ont été évalués en utilisant la technique des sacs à litière. La masse totale des nutriments dans les strates organiques et les caractéristiques chimiques de la partie supérieure $(0-20 \mathrm{~cm})$ du sol ont été estimées au bout de huit ans.

- La perte de masse et la libération de N, P, Ca et Mg provenant des feuilles et des bogues enfouies dans le sol ont été plus rapides que dans le cas de feuilles et bogues placées à la surface du sol. Les bogues se décomposent et libèrent des nutriments plus lentement que les feuilles de la litière. Le système d'absence de labour a conduit à la formation de strates organiques, qui retiennent une grande quantité de $\mathrm{N}\left(249,2 \mathrm{Kg}\right.$ ha $\left.{ }^{-1}\right)$ et de $\mathrm{Ca}(215,5 \mathrm{~kg}$ $\left.\mathrm{ha}^{-1}\right)$. Un tel système de gestion a accru la concentration en $\mathrm{C}$ organique et en nutriments dans la strate de la partie supérieure du sol $(0-5 \mathrm{~cm})$, mais des différences significatives ont été observées seulement pour le Ca échangeable.

- Le système sans labour peut accroître l'accumulation de C organique par rapport au système traditionnel à cause de l'accroissement dans les deux strates organique et minérale.

décomposition des chutes de litière / sac à litière / dynamique des nutriments / peuplement de châtaignier / gestion du sol / modèles de décomposition / non labour / labour traditionnel

\section{INTRODUCTION}

Chestnut stands for fruit production cover about 25000 ha in Northern Portugal (INE, 2005), which are usually subjected to intensive management. The common management system includes frequent soil tillage operations, usually with a chisel plow (two or three times per year), removal of the pruning biomass and low application of organic fertilizers. Tillage operations are used to incorporate leaves and burs into the soil

* Corresponding author: fraimund@utad.pt and to control weeds, with the objective of reducing competition for water and nutrients. However, this system has been reported as the most important factor for physical, chemical and biological soil degradation (Portela et al., 1999; Raimundo et al., 2001) in the abovementioned chestnut stands. Therefore, it is necessary to establish management systems in chestnut stands to improve their productivity and sustainability, and to ameliorate soil quality. In this context, it is crucial to identify the most appropriate soil tillage systems, considering site litter management. 
Minimum tillage or no-tillage are thought to be the management systems indispensable for achieving the abovementioned objectives, constituting an alternative to improve physical, chemical and biological soil properties (Holland, 2004; Lal, 1994). Therefore, a field trial was installed in a 50-yearold chestnut stand (in autumn 1995), to assess the effects of soil management on soil physical and chemical properties and chestnut stand productivity and sustainability. For that, conventional tillage (chisel plow up to a depth of $15 \mathrm{~cm}$, some years it was done twice in February-March and May-June, and others three times in the periods mentioned before and also in September), disc harrowing tillage (average depth $7 \mathrm{~cm}$, twice a year, February-March, May-June), and the no-tillage system with spontaneous herbaceous vegetation were used. Minimum soil tillage or no-tillage may affect the decomposition rate and nutrient release dynamics of leaves and burs, as the decomposition rate of residues maintained on the soil surface has been observed to be slower than that of those incorporated into the soil (Azevedo et al., 2004; Gregorich and Ellert, 1994; Holland and Coleman, 1987). As decomposition of litter is an important step of the system nutrient cycling, it is very useful for assessing the amounts of nutrients delivered to the soil according to the litter management. Although the no-tillage system may lead to an increase in soil organic matter content, which is a basic condition for the stability of forest and agro-forest systems (Lal, 1994), the evaluation of its effects on the amount of soil organic layers and the soil chemical characteristics is needed.

Therefore, a decomposition experiment was carried out in the abovementioned field trial to test the effects of replacing the conventional soil tillage by the no-tillage system on the decomposition rate and nutrient release dynamics of the chestnut leaves and burs. In addition, the decomposition experiment also aimed to understand how the amount of mass and nutrients in the soil organic layer and chemical characteristics of the $0-20 \mathrm{~cm}$ top soil layer are affected by the soil tillage system.

\section{MATERIALS AND METHODS}

\subsection{Site characteristics}

The experimental site is located in Northeast Portugal $\left(41^{\circ} 36^{\prime} \mathrm{N}\right.$, $6^{\circ} 56^{\prime} \mathrm{W}$; alt. $760 \mathrm{~m}$ ), within the main chestnut stand region. The climate is Mediterranean with cool wet winters and warm dry summers. At the meteorological station of Bragança (30 km from the site), the mean annual rainfall is $743 \mathrm{~mm}$ (1961-1990), mainly concentrated from October to May $(85 \%)$; the mean annual temperature is $12.2{ }^{\circ} \mathrm{C}$, which ranges from $4.5^{\circ} \mathrm{C}$ in winter (January) to $21.1{ }^{\circ} \mathrm{C}$ in summer (August) (Instituto de Meteorologia, 2007).

The accumulated rainfall at the experimental site during the decomposition experiment (from March 1996 to June 1998) was 2338 mm (Fig. 1). From March 1996 to September 1997, the rainfall followed the mean observed in the 1961-1990 period (Bragança), while it was higher from October 1997 to the end of spring 1998. Air temperature ranged from $3.4{ }^{\circ} \mathrm{C}$ in winter (December 1997) to $22.2^{\circ} \mathrm{C}$ in summer (August 1997), close to that observed during the period 1961-1990 at the meteorological station of Bragança.

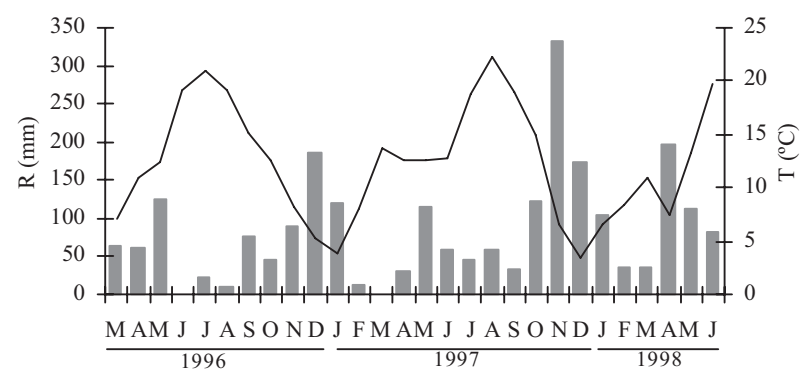

Figure 1. Mean monthly air temperature (continuous line) and monthly rainfall (vertical bars) at the site during the litter decomposition experiment.

The landscape of the study area is gently undulating with slopes varying from 0 to $4 \%$. The soils are mostly Regosols and Cambisols (WRB, 2006) developed on metamorphic rocks (schists) of the Siluric formation. The soil is acidic, with low organic carbon and extractable $\mathrm{P}$ contents and high extractable $\mathrm{K}$, and with loam texture. Selected soil properties down to $20 \mathrm{~cm}$ depth are shown in Table I.

The native vegetation of the region is Quercus pyrenaica forest of the Genisto falcatae-Quercetum pyrenaicae phytosociological association (Costa et al., 1998). The main spontaneous vegetation in the area includes Genista falcate, Cistus spp., Cytisus spp., Bromus diandrus, Chamaemelum mixtum, Cynosurus cristatus, Hypochoeris radicata, Ornithopus compressus, Ornithopus perpusilus, Rumex angiocarpus, Trifolium arvense and Vulpia bromoides.

\subsection{Litter decomposition experiment}

The decomposition experiment was carried out in a field trial installed (in autumn 1995) in a 50-year-old chestnut stand in which conventional tillage, disc harrowing tillage and no-tillage systems were installed. Treatments were applied in $30 \mathrm{~m} \times 40 \mathrm{~m}$ plots and replicated four times. Trees were spaced about $12 \times 12 \mathrm{~m}$, and showed a diameter at breast height of $38.5 \mathrm{~cm}$, a height of $8.8 \mathrm{~m}$ and a tree crown diameter of $10 \mathrm{~m}$. Organic fertilizers (adapted to biological chestnut production), fertigafsa $(26.5 \%)$ and calcitic calcareous were applied annually (in March) in all treatments during the study period (1995-2003), corresponding to $8.2,15.3$ and $102.8 \mathrm{~kg} \mathrm{ha}^{-1}$, respectively, of $\mathrm{N}, \mathrm{P}$ and $\mathrm{Ca}$; amounts for $\mathrm{K}$ and $\mathrm{Mg}$ were $2.5 \mathrm{~kg} \mathrm{ha}^{-1}$. The decomposition experiment was installed in the no-tillage plots.

Collection of leaves and burs (representing 49.8 and $39.8 \%$, respectively, of the annual litterfall) took place in autumn (November 1995), immediately after the leaf fall. The collected material was firstly dried at $45^{\circ} \mathrm{C}$, and the dry mass of each material to be placed into litterbags was determined on 12 samples (dried at $80^{\circ} \mathrm{C}$ ).

Litterbags were made of nylon net with a mesh size of about $1 \mathrm{~mm}$, with a surface area of $250 \mathrm{~cm}^{2}$ for leaves and $350 \mathrm{~cm}^{2}$ for burs. A set of 160 litterbags of leaves was used: in each, $5 \mathrm{~g}$ of leaves were kept. A set of 240 litterbags was used for bur decomposition assessment. A greater weight of burs was placed in each litterbag (15 g) to be representative, because the weight of each bur is much greater than that of a single leaf. Half of each set was placed on the soil surface and the other buried in the soil. In each plot of the no-tillage treatment, two randomized sub-plots of $2 \times 3 \mathrm{~m}$, in the crown projection area, were established for litterbag placement. The litterbags were incubated (7 March 1996) on the soil surface (fastened to the 
Table I. Selected soil characteristics of the Castanea sativa stand when the decomposition experiment began.

\begin{tabular}{|c|c|c|c|c|c|c|c|c|}
\hline $\begin{array}{l}\text { Depth } \\
(\mathrm{cm})\end{array}$ & $\begin{array}{c}\text { Org C } \\
\left(\mathrm{g} \mathrm{kg}^{-1}\right)\end{array}$ & \multicolumn{2}{|c|}{ Extractable $^{a}\left(\mu \mathrm{g} \mathrm{g}^{-1}\right)$} & $\begin{array}{c}\mathrm{pH} \\
\left(\mathrm{H}_{2} \mathrm{O}\right)\end{array}$ & \multicolumn{4}{|c|}{ Exchangeable cations $\left(\mathrm{cmol}_{c} \mathrm{~kg}^{-1}\right)$} \\
\hline $10-20$ & 17.1 & 7.7 & 89.3 & 5.07 & 0.54 & 0.19 & 0.29 & 0.91 \\
\hline
\end{tabular}

${ }^{\mathrm{a}}$ By the Egnér-Riehm method; ${ }^{\mathrm{b}}$ Extracted by ammonium acetate at $\mathrm{pH} 7 ;{ }^{\mathrm{c}}$ Extracted by $1 \mathrm{M} \mathrm{KCl}$.

ground by $10-15-\mathrm{cm}-$ long metal pegs) or in the soil by burying with a shovel at $5 \mathrm{~cm}$ depth, and sampled 40 and 90 days after incubation and, afterwards, at three-month intervals for an experimental period of 2.25 years. At each sampling interval and subplot location, eight litterbags with leaves and twelve with burs were collected from the sub-plots. The content of each litterbag was dried at $80{ }^{\circ} \mathrm{C}$ and, after cleaning, was weighed to determine the respective dry mass. From the total litterbag content, a composite sample for each placement and litter type was obtained, ground through a 1-mm screen, and then analyzed.

\subsection{Soil sampling}

Total mass of organic layers (forest floor litter layer) in no-tillage was assessed eight years after the installation of the treatments (October 2003). Samples of organic residues were collected in a grid $(0.7 \times 0.7 \mathrm{~m})$, randomly placed in the plot area; twelve samples were taken in the tree crown projection area and twelve others at the middle distance between crowns. Samples were not collected in the conventional tillage plots, as organic layers were absent due to soil tillage operations. In both conventional and no-tillage plots, an assessment of chemical characteristics in the $0-5,5-10$ and $10-20 \mathrm{~cm}$ mineral soil layers was also made, by collecting twelve samples per treatment in each soil layer beneath the tree crown projection area.

\subsection{Chemical analysis}

\subsubsection{Organic residues}

Organic matter content in decomposing residues and organic layers was determined by ignition loss after heating at $450{ }^{\circ} \mathrm{C}$ for $6 \mathrm{~h}$. Samples of these organic residues were digested with sulfuric acid, subsequently followed by colorimetric method measurements of $\mathrm{N}$ and $\mathrm{P}$ concentrations using an autoanalyzer. For $\mathrm{K}, \mathrm{Ca}, \mathrm{Mg}$ and $\mathrm{S}$ determinations, samples were digested with nitric-perchloric acid, $\mathrm{Ca}$ and $\mathrm{Mg}$ being determined by atomic absorption spectrophotometry (AAS), K by flame photometry and $\mathrm{S}$ by the turbidimetric method. Organic $\mathrm{C}$ content evaluation was based on the assumption that $\mathrm{C}$ content was $50 \%$ of organic matter. Lignin (Klason) was determined by the method described by Effland (1977).

\subsubsection{Soil material}

Organic $\mathrm{C}$ content in the mineral soil layers was determined at $1100{ }^{\circ} \mathrm{C}$ in an elementary autoanalyzer. The base cations were extracted by $1 \mathrm{M}$ ammonium acetate, adjusted to $\mathrm{pH} 7$; the $\mathrm{Ca}$ and $\mathrm{Mg}$ were determined by AAS, and K by flame photometry. Exchangeable $\mathrm{Al}$ was determined after extraction with $1 \mathrm{M} \mathrm{KCl}$ and determined by titration. Extractable P and $\mathrm{K}$ were obtained by the Egnér-Riehm method. The $\mathrm{pH}$ was measured in a 1:2.5 soil water suspension.
Table II. Initial concentrations of ash, organic C, nutrients, Klason lignin, and $\mathrm{C}: \mathrm{N}$ and $\mathrm{C}: \mathrm{P}$ ratios of chestnut leaves and burs used in the decomposition experiment. Contents are expressed on a dry $\left(80{ }^{\circ} \mathrm{C}\right)$ mass basis.

\begin{tabular}{lccccccccccc}
\hline Litter & Ash & $\mathrm{C}$ & $\mathrm{N}$ & $\mathrm{P}$ & $\mathrm{K}$ & $\mathrm{Ca}$ & $\mathrm{Mg}$ & $\mathrm{S}$ & Lignin & C:N & $\mathrm{C}: \mathrm{P}$ \\
\cline { 2 - 9 } & \multicolumn{10}{c|}{$\mathrm{mg} \mathrm{g}^{-1}$} \\
\hline Leaves & 55 & 473 & 8.9 & 1.4 & 6.4 & 10.1 & 2.4 & 0.3 & 272 & 53.8 & 338 \\
Burs & 50 & 475 & 5.7 & 1.2 & 5.3 & 4.7 & 1.2 & 0.2 & 131 & 83.3 & 379 \\
\hline
\end{tabular}

\subsection{Data analysis}

The annual decay rate $(k)$ was estimated by the exponential model $X=X_{0} \mathrm{e}^{-k t}$ (Olson, 1963), where $X$ is the remaining litter mass in the litterbags at time $t$ (years) and $X_{\mathrm{o}}$ the initial mass of the same material. A linear model, the best-adjusted model according to Wieder and Lang (1982) when a very small amount of mass is lost over the decomposition course, was also used to estimate the decomposition rate of leaves and burs. The leaves' and burs' half-life $\left(t_{1_{1}}\right)$ was estimated as $t_{1 / 2}=\ln (0.5) /-k$ (Tutua, 2002). The amount of remaining organic matter was calculated by the ratio between the litter mass after each incubation period and the respective initial mass; only free ash material was used to avoid the influence of mineral matter. The remaining nutrient proportions in decomposed substrates were calculated by the ratio between the amount of nutrients after each incubation period and the initial amount.

Data were analyzed using JMP 5.0.1.2. (SAS Institute Inc). Differences among litters (leaves and burs) and placements regarding remaining mass and decay rates were compared using one-way analysis of variance (ANOVA) and the Tukey HSD multiple comparison test. Soil chemical characteristics were analyzed using the same procedure. Correlation coefficients were determined by Pearson correlation analysis.

\section{RESULTS AND DISCUSSION}

\subsection{Litter decomposition}

\subsubsection{Initial substrate characteristics}

The leaves and burs used in the decomposition experiment showed identical initial $\mathrm{C}$ content. Leaves had greater contents of nutrients than burs (Tab. II), differences being larger for $\mathrm{Ca}$, $\mathrm{Mg}$ and $\mathrm{N}$. Therefore, the $\mathrm{C}: \mathrm{N}$ ratio was much higher for burs (83.3) than for leaves (53.8), while values of the $C: P$ ratios were 379 and 338, respectively. A very small content of S was observed in both leaves and burs, corresponding in the former to a $C: S$ ratio (1540) much higher than that reported for 
Table III. Remaining mass (RM), annual decomposition rate ( $k$, exponential model; $m$, linear model) and $R^{2}$ values for the first year and the whole incubation period (2.25 years) of leaves (Le) and burs (Bu) decomposed on the surface (Sur) or buried in the soil (Bur).

\begin{tabular}{|c|c|c|c|c|c|c|c|c|c|}
\hline \multirow[b]{2}{*}{ Treatment } & \multirow[b]{2}{*}{$n$} & \multicolumn{3}{|c|}{1 year } & \multicolumn{5}{|c|}{2.25 years } \\
\hline & & $\begin{array}{l}\mathrm{RM} \\
(\%)\end{array}$ & $\begin{array}{c}k \\
\left(\text { year }^{-1}\right)\end{array}$ & $R^{2}$ & $\begin{array}{l}\mathrm{RM} \\
(\%)\end{array}$ & $\begin{array}{c}k \\
\left(\text { year }^{-1}\right)\end{array}$ & $R^{2}$ & $\begin{array}{c}m \\
\left(\text { year }^{-1}\right)\end{array}$ & $R^{2}$ \\
\hline LeSur & 8 & $63.2 \mathrm{~b}$ & $-0.39 c$ & 0.92 & $32.4 \mathrm{~b}$ & $-0.48 \mathrm{c}$ & 0.97 & $-32.1 \mathrm{c}$ & 0.99 \\
\hline LeBur & 8 & $39.4 \mathrm{~d}$ & $-0.94 \mathrm{a}$ & 0.95 & $12.5 \mathrm{c}$ & $-0.95 \mathrm{a}$ & 0.98 & $-46.9 \mathrm{a}$ & 0.82 \\
\hline BuSur & 12 & $81.6 \mathrm{a}$ & $-0.17 \mathrm{~d}$ & 0.90 & $49.7 \mathrm{a}$ & $-0.26 \mathrm{~d}$ & 0.89 & $-20.2 \mathrm{~d}$ & 0.94 \\
\hline BuBur & 12 & $50.3 \mathrm{c}$ & $-0.74 \mathrm{~b}$ & 0.88 & $20.3 \mathrm{c}$ & $-0.69 \mathrm{~b}$ & 0.98 & $-40.6 b$ & 0.83 \\
\hline
\end{tabular}

$n$, Number of replications; Different letters in the same column indicate statistically significant differences $(P<0.05)$ between residues by Tukey HSD multiple comparison test.

other Mediterranean tree species (Ribeiro et al., 2002; Wesemael, 1993). Leaves had greater content of lignin than burs, and therefore the lignin/ $\mathrm{N}$ ratio was greater in leaves (36) than in burs (23).

\subsubsection{Litter-mass loss and decay rates}

The mass loss of leaves buried in the soil (LeBur) was significantly greater than that observed for those placed on the soil surface (LeSur). At the end of the incubation period, the LeSur remaining mass was still $32.4 \%$ of the initial mass, while for the LeBur it was only $12.5 \%$ (Tab. III). Differences in mass loss between LeBur and LeSur during the incubation period began to occur in the early phase of decomposition. Considering the whole decomposition period, the annual decay rate for the LeSur $(-0.48)$ was significantly lower than for LeBur (-0.95), which is in agreement with results reported by Azevedo et al. (2004) and Jones et al. (1999) for harvest residues of eucalypt plantations in Portugal. The annual decay rate of the LeSur increased from the first year to the end of the decomposition experiment, while that of LeBur was approximately constant (Tab. III). Half-lives were about 1.44 and 0.73 years for LeSur and LeBur, respectively.

As observed for leaves, burs buried in the soil (BuBur) decomposed faster than those placed on the soil surface (BuSur), showing at the end of the incubation period 20.3 and $49.7 \%$, respectively, of the initial mass (Tab. III). Differences between BuBur and BuSur, regarding remaining mass, mostly occurred during the first three months of incubation (Fig. 2). The annual decay rate, for the incubation period, was -0.69 for BuBur and -0.26 for BuSur (Tab. III), and half-lives were 1.00 and 2.67 years for BuBur and BuSur, respectively. The slower decomposition of burs, both on the surface or buried in the soil, as compared with leaf litter, may be explained by a smaller $\mathrm{N}$ content and higher $\mathrm{C}: \mathrm{N}$ ratio (Tab. II), as the lignin content in burs was about half of that measured for leaves. In fact, it has been reported that decomposition of different litter types with a lignin/ $\mathrm{N}$ ratio above 20 is mostly related to differences in $\mathrm{N}$ content and the C:N ratio (Harmon et al., 1990).

The faster decomposition observed for buried leaf litter and burs (Fig. 2) may be related to the close contact with soil organisms and the insulation from fluctuating air humidity and temperature as experienced by surface-placed residues (Elliott and Stott, 1997; Kumar and Goh, 2000; Schomberg

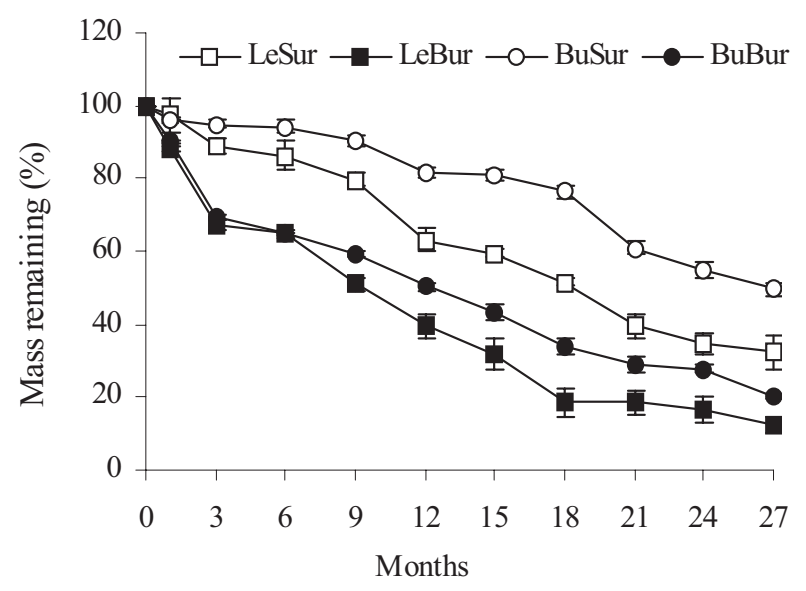

Figure 2. Remaining mass evolution of the leaves (Le) and burs (Bu) placed on the surface (Sur) or buried (Bur) in the soil.

et al., 1994). Besides, Douglas et al. (1980), and Holland and Coleman (1987) reported that organic matter losses could also be affected by the existing microorganism populations, being greater in the soil in the case of bacterial than in fungal prevalence. In litter incubated on the soil surface, due to the fluctuating air temperature and humidity conditions, fungal development is favored to the detriment of the bacterial and slower decomposition occurs (Beare et al., 1992; Holland and Coleman, 1987; Wardle, 1995).

Mass loss of leaves placed on the soil surface, one year after incubation, was similar to that reported by Santa-Regina et al. (1986) for the same species, in a study carried out at Béjar Mountain (province of Salamanca, Spain), where the mean annual temperature is $11{ }^{\circ} \mathrm{C}$ and the mean annual rainfall is $1000 \mathrm{~mm}$. The leaf litter decay rate for such a placement was, however, lower $(-0.39)$ than that reported by Martins et al. (2007) $(k=-0.60)$ in a 15-year-old chestnut stand (with a tree density of 1438 trees/ha) exploited for wood (diameter at breast height of $14.7 \mathrm{~cm}$ and height of $13.3 \mathrm{~m}$ ) in Northeast Portugal. As the annual mean rainfall is much higher $(1381 \mathrm{~mm})$ in this site than the present experimental site, it suggests that the increment in the annual amount of rainfall may have a positive influence on the decomposition rate of chestnut leaf litter. In addition, the decomposition rate of the LeSur $(-0.48)$ was much lower than that observed by Pereira 

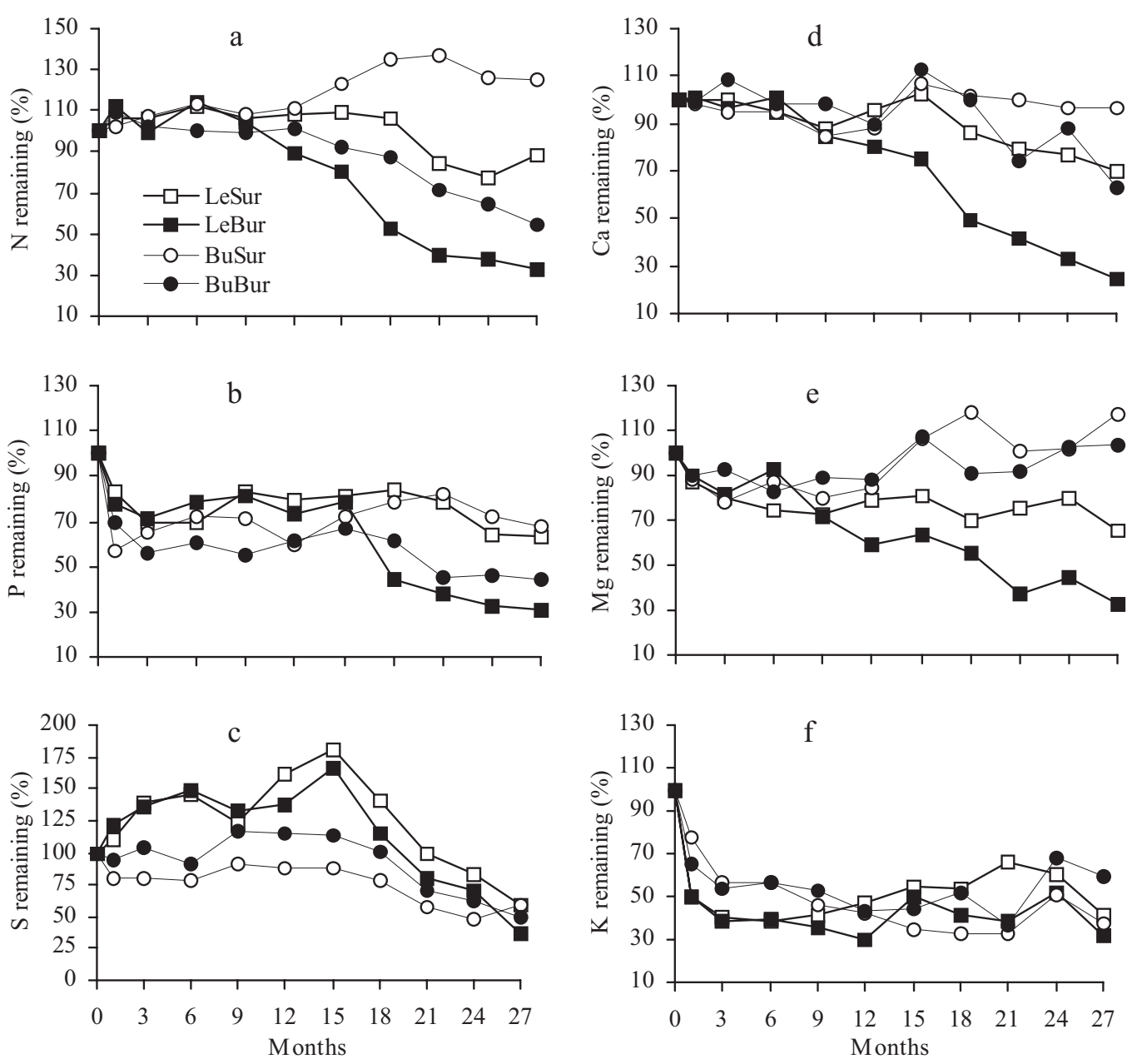

Figure 3. Nutrient dynamics of the leaves (Le) and burs (Bu) placed on the surface (Sur) or buried in the soil (Bur). Scale differences on $y$-axes.

(2004) in the same region for leaf litter of Fraxinus angustifolia (-0.96).

The increase in the decay rate observed for the LeSur, over the incubation period, followed the pattern reported by Gallardo-Lancho et al. (1995) for a chestnut forest in the Sierra da Gata (mean air temperature of $15{ }^{\circ} \mathrm{C}$ and mean rainfall of $1150 \mathrm{~mm}$ ), in which decay rates were -0.21 and -0.46 for one and two years of incubation, respectively. This decomposition pattern (also observed for the BuSur) may be specific to chestnut leaf litter, as decomposing leaves of other species, in Portugal, placed on the soil surface (Azevedo, 2004; Pereira, 2004; Ribeiro et al., 2002) showed a faster mass loss during the initial phase of the decomposition process.

For the whole incubation period, the linear model described the LeSur $\left(R^{2}=0.99\right)$ and BuSur $\left(R^{2}=0.94\right)$ decay rates better, while the exponential model described the LeBur $\left(R^{2}=\right.$ $0.98)$ and BuBur $\left(R^{2}=0.98\right)$ decay rates (Tab. III). Despite the exponential model being the most used in decomposition studies, Wieder and Lang (1982) considered that, in the case of very small mass loss over the course of decomposition, a linear function was the best fit to data, at least for the first two years. In fact, in the decomposition experiment, the initial decay rates of LeSur and BuSur were relatively lower than in the remaining incubation period, which best explains the linear model adaptation. The lower decay rate, in the early phase of the incubation, for the litter decomposing on the soil surface, may be related to the stronger fluctuation of air humidity and temperature experienced on the soil surface (Schomberg et al., 1994).

\subsubsection{Nutrient dynamics during decomposition}

During the first nine months of incubation, net $\mathrm{N}$ release from the decomposing substrates was not observed (Fig. IIIa). After that, a net $\mathrm{N}$ release occurred until the end of the incubation period for LeBur and BuBur. However, residues decomposing on the soil surface showed a different pattern. The net $\mathrm{N}$ release from the LeSur was only recorded after 18 months of incubation, while in the BuSur it was not observed during the incubation period. Mass loss and $\mathrm{N}$ release rates showed positive correlations for the LeSur $(r=0.71, P<0.05)$, LeBur 

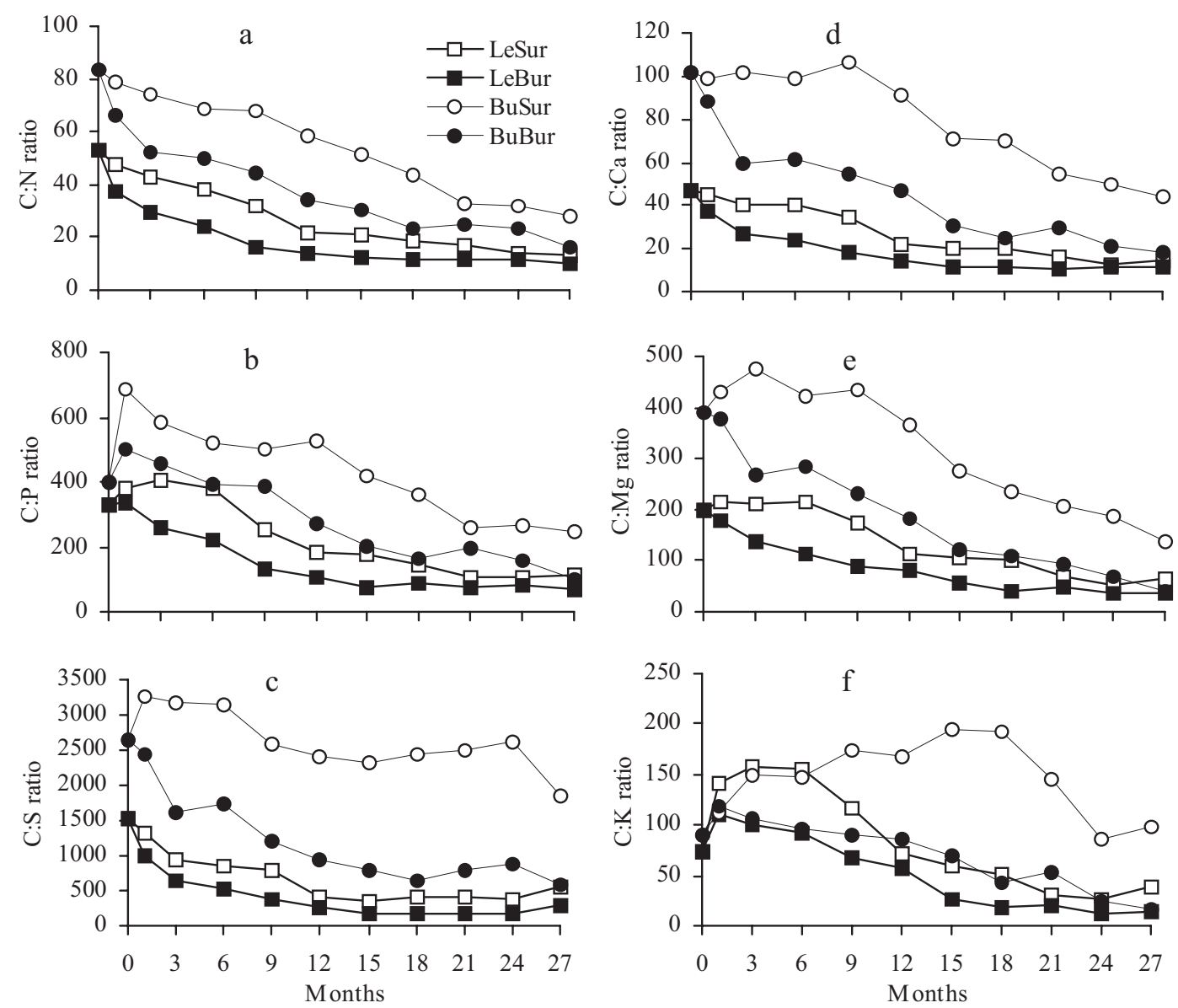

Figure 4. Evolution of ratios between $\mathrm{C}$ and $\mathrm{N}, \mathrm{P}, \mathrm{K}, \mathrm{Ca}, \mathrm{Mg}$ and $\mathrm{S}$ of leaves (Le) and burs (Bu) placed on the surface (Sur) or buried in the soil (Bur).

$(r=0.87, P<0.001)$ and BuBur $(r=0.82, P<0.01)$ and a negative correlation for the BuSur $(r=-0.79, P<0.01)$. The increase in $\mathrm{N}$ absolute amount observed, during a long period of incubation, for leaves decomposing on the soil surface, is in agreement with data reported by Santa-Regina et al. (1986) for chestnut leaves, and for other Mediterranean tree species (Wesemael, 1993). This is attributable to the microbial external $\mathrm{N}$ immobilization associated with litter decomposition, which may be related to several external $\mathrm{N}$ origins, such as atmospheric deposition, throughfall, insect activity and fungal translocation (Frey et al., 2000; Joergensen and Meyer, 1990).

As the litter $\mathrm{N}$ release rate was mostly lower than the $\mathrm{C}$ release rate, a continuous decrease in the $\mathrm{C}: \mathrm{N}$ ratio was observed (Fig. 4a), and this ratio was close to 12:1 (LeBur and LeSur), 16:1 (BuBur) and 30:1 (BuSur) at the end of the incubation period. The $\mathrm{C}: \mathrm{N}$ ratio has been reported as a good indicator of $\mathrm{N}$ mineralization for a wide range of litter types (Ribeiro et al., 2002; Wesemael, 1993). According to Wesemael (1993), the $\mathrm{C}: \mathrm{N}$ ratio from which $\mathrm{N}$ mineralization starts should be in the range 20-30. In the decomposition experiment, the 30:1 (C:N) ratio values were reached $3,10,16$ and 26 months after the incubation for the LeBur, LeSur, BuBur and BuSur, respectively
(Fig. 4a), but no $\mathrm{N}$ mineralization was observed. The $\mathrm{N}$ mineralization in leaves began when the respective $\mathrm{C}: \mathrm{N}$ ratio was close to 20:1. By the end of the incubation, the $\mathrm{C}: \mathrm{N}$ ratio in the BuSur was still 28:1, indicating that the critical conditions for $\mathrm{N}$ release may not have been achieved.

In contrast with that observed for $\mathrm{N}$, the $\mathrm{P}$ amount of leaves and burs strongly decreased during the early decomposition phase (Fig. 3b), and the release was more accentuated than the mass loss, which agrees with the increase in the C:P ratio (Fig. 4b). The fast loss of $\mathrm{P}$ observed during the early decomposition stages is in agreement with results reported for leaf litter of a chestnut stand exploited for wood (Martins et al., 2007) and several leaf litters and needles of other forest species (Buchanan and King, 1993; Pereira, 2004; Ribeiro et al., 2002; Sá et al., 2005). The fast initial P release from leaf litter, by both direct leaching and microbial biomass, increased with the litter P content (Ribeiro et al., 2002) or with inorganic P (soluble) present in plant residues (Buchanan and King, 1993). The high initial $\mathrm{P}$ content in studied litters may thus explain the high initial $P$ release.

After the early loss of $\mathrm{P}$, no further losses were observed until 15 months for LeBur and BuBur and until 18 months of incubation for LeSur and BuSur. According to Lousier and 
Parkinson (1978) and Stevenson (1986), P net mineralization would not occur for C:P ratios greater than 200-480, which agrees with our results. In fact, P mineralization was only observed in the LeBur and LeSur when the C:P ratio approached 100 , while mineralization began when this ratio was close to 200 in the BuBur, and about 300 in the BuSur. These results also suggest that the critical $\mathrm{C}: \mathrm{P}$ ratio at which net $\mathrm{P}$ mineralization begins depends on the litter type (and composition) and its placement in the soil. Therefore, other factors than the $\mathrm{C} / \mathrm{P}$ ratio are also critical for determining $\mathrm{P}$ mineralization.

Several authors have reported strong correlations between mass loss and $\mathrm{P}$ release rates for litter decomposing on the soil surface (Lousier and Parkinson, 1978). In the present case, positive correlations were only observed between $\mathrm{P}$ release and mass loss for incorporated residues (LeBur, $r=0.85$, $P<0.001$; BuBur, $r=0.80, P<0.01)$.

The absolute amount of $\mathrm{S}$ in decomposing leaves (LeSur and LeBur) increased rapidly and was maximum 15 months after the start of incubation (Fig. 3c), which led to a strong decrease in their C:S ratio (Fig. 4c). The absolute increase in $\mathrm{S}$ may be associated with the very low initial $\mathrm{S}$ content in leaf litter $(C: S=1540)$. However, a different pattern was observed for decomposing burs. As for $\mathrm{P}$, the BuSur showed an initial $\mathrm{S}$ loss (and an increase in the $\mathrm{C}: \mathrm{S}$ ratio) and, after 15 months, the amount was close to the initial (87\%), while the BuBur showed a slight increase (114\%). After 15 months of incubation, both leaves and burs showed a gradual decrease in the S amount, which was similar among residues (37 to 59\% of the initial amount) at the end of the decomposition experiment. The release of S from decomposing leaves only took place when the C:S ratio ranged from 173 to 362 , which is close to the critical $\mathrm{C}: \mathrm{S}$ ratio (200) at which $\mathrm{S}$ net mineralization is considered to begin (Wesemael, 1993). Although less pronounced, net S release from both surface and buried burs occurred when the C:S ratio was much higher (657 for BuBur and 2436 for BuSur) than the abovementioned critical value, suggesting that $\mathrm{S}$ release dynamics is not only dependent on the C:S ratio.

The amount of $\mathrm{Ca}$ in leaves and burs declined slightly during the first 9 months of decomposition (Fig. 3d), which led to the $\mathrm{C}: \mathrm{Ca}$ ratio decrease, especially in the LeBur and BuBur (Fig. 4d). After that, the net release of $\mathrm{Ca}$ was stronger from LeBur than from LeSur. The BuBur showed a net release of $\mathrm{Ca}$ only after 18 months of incubation, while the release of $\mathrm{Ca}$ from the BuSur was negligible. The pattern of $\mathrm{Ca}$ release was similar to that observed for $\mathrm{N}$ for the LeSur, LeBur and BuBur, positive correlations being obtained between these two nutrients (LeSur, $r=0.80, P<0.01$; LeBur, $r=0.98$, $P<0.001$; BuBur, $r=0.78, P<0.01$ ). The slow release of $\mathrm{Ca}$ in the initial phase of decomposition is in agreement with results reported by Santa-Regina et al. (1986) and GallardoLancho et al. (1995) for chestnut leaf litter decomposing on the soil surface, and by Azevedo et al. (2004), Pereira (2004) and Sá (2001) for leaf litter of several other species in Portugal. This slow Ca release may be related to its presence in pectic substances occurring in the cellular wall structure, which are one of the most resistant vegetable compounds to decomposition (Ricardo and Teixeira, 1977). Therefore, the low mobility showed by Ca during the first year of the incubation indicates that its release depends on biological activity rather than on leaching (Ribeiro et al., 2002), which is corroborated by positive correlations between the decomposition rate and the $\mathrm{Ca}$ release rate (Staaf and Berg, 1982). In fact, significant positive correlations between mass loss and $\mathrm{Ca}$ release rates were observed in the decomposition experiment for leaves (LeSur, $r=0.83, P<0.01$; LeBur, $r=0.91, P<0.001)$.

In contrast to $\mathrm{Ca}$, a net release of $\mathrm{Mg}$ from LeSur and LeBur was observed during the first 6 months of incubation, this release being less marked than for K (Fig. 3e). Over the incubation period, the $\mathrm{Mg}$ release rate from leaves was positively correlated with that of $\mathrm{Ca}$ (LeSur, $r=0.63, P<0.05$; LeBur, $r=0.95, P<0.001)$ and, at the end of the incubation, the remaining $\mathrm{Mg}$ amount was much less in the LeBur (33\%) than in LeSur (66\%). The Mg variation pattern in the burs was different from that of leaves, as the increase in the absolute amount lasted until the end of the incubation. The $\mathrm{Mg}$ release rate from the leaves was also positively correlated with mass loss (LeSur, $r=0.62, P<0.05$; LeBur, $r=0.96, P<0.001$ ), $P$ (LeSur, $r=0.64, P<0.05$; LeBur, $r=0.89, P<0.001$ ) and $\mathrm{K}$ (LeSur, $r=0.75, P<0.01$ ). The Mg release pattern from the LeSur was similar to that reported by GallardoLancho et al. (1995) for leaf litter of chestnut. The initial loss of $\mathrm{Mg}$ may be explained by the fact that the major part of $\mathrm{Mg}$ is not structurally bound to organic matter (Marschner, 1995). Magnesium immobilization observed in burs during the last year of the decomposition experiment can be attributed to microbial immobilization or to low initial $\mathrm{Mg}$ concentrations in litter, according to data reported by Staaf and Berg (1982).

The $\mathrm{K}$ was released faster than either $\mathrm{Ca}$ or $\mathrm{Mg}$ (Fig. 3f). Such a release is mostly related to $\mathrm{K}$ leaching and, therefore, was concomitant with the strong increase in the $\mathrm{C}: \mathrm{K}$ ratio (Fig. 4f). The release pattern of $\mathrm{K}$ was similar among the studied substrates and litter placements. The fast release of $\mathrm{K}$ during the early decomposition stages of chestnut leaf litter is in agreement with data reported by Santa-Regina et al. (1986) and Martins et al. (2007) for the same species, and by Azevedo et al. (2004), Pereira (2004) and Ribeiro et al. (2002) for leaf litter and other residues of several forest species in Portugal. The low proportion of $\mathrm{K}$ remaining early in the incubation (Fig. 3f) is consistent with the high mobility of K, due to lack of incorporation of this element into organic structures (Marschner, 1995).

\subsection{Residue management and nutrient dynamics}

The average annual production of leaf litter and burs in the experimental site reached 1.82 and $1.46 \mathrm{tha}^{-1}$ year ${ }^{-1}$, respectively (Ana Luísa Pires, personal communication), which represented $89.6 \%$ of the total litterfall, and twigs and inflorescences were only 0.6 and $9.7 \%$, respectively. According to their average chemical composition (Tab. II), leaf litter and burs presented great annual fluxes of $\mathrm{N}, \mathrm{K}$ and $\mathrm{Ca}(24.5,19.4$ and $25.2 \mathrm{~kg} \mathrm{ha}^{-1}$, respectively), of which less than one-third corresponded to burs; the annual fluxes of $\mathrm{P}, \mathrm{Mg}$ and $\mathrm{S}$ were much smaller $\left(3.29,6.12\right.$ and $0.84 \mathrm{~kg} \mathrm{ha}^{-1}$, respectively). 
Table IV. Amounts of organic matter $(\mathrm{OM})$ and nutrients accumulated over an eight-year period in soil organic layers under the tree canopy and in the open for the no-tillage treatment.

\begin{tabular}{lcccccc}
\hline Situation & $\mathrm{OM}$ & $\mathrm{N}$ & $\mathrm{P}$ & $\mathrm{K}$ & $\mathrm{Ca}$ & $\mathrm{Mg}$ \\
\hline & \multicolumn{7}{c}{$\left(\mathrm{kg} \mathrm{ha}^{-1}\right)$} \\
\hline Under canopy & 13722.5 & 249.2 & 30.7 & 261.1 & 215.5 & 44.5 \\
In the open & 4256.2 & 106.0 & 15.9 & 274.1 & 83.2 & 29.6 \\
\hline
\end{tabular}

A large mass of buried residues (87.5 and $79.7 \%$ for leaves and burs, respectively) was lost over the incubation period. To simulate the traditional soil tillage system in chestnut stands, soil was disturbed once to bury residues. However, soil disturbance in the chestnut stands under conventional tillage was much more intensive than in our decomposition experimental conditions, as soil tillage operations during the year, according to findings of Diekow et al. (2005) and Heenan et al. (2004), may have enhanced soil aeration and accelerated the decomposition of residues. Therefore, we would expect that the decomposition of residues would be faster in the chestnut stands under conventional tillage than in our experimental conditions. We emphasize that, due to soil tillage operations, the forest floor litter layer was absent in the conventional tillage system.

The placement of leaves and burs on the soil surface led to a substantial decrease in the respective decomposition rate, which is in agreement with the mass of organic matter measured in organic layers under the tree crown $\left(13.72 \mathrm{t} \mathrm{ha}^{-1}\right)$ and in the open area $\left(4.26 \mathrm{t} \mathrm{ha}^{-1}\right)$, eight years after the installation of the no-tillage system (Tab. IV). The amount of organic matter in the organic layers beneath the tree crown was about $50 \%$ of the total amount of litter fallen during the study period (eight years). Besides the contribution to reducing soil erosion, those organic layers may also contribute to controlling the understory vegetation, as the respective biomass was only $0.62 \mathrm{t} \mathrm{ha}^{-1}$ in the no-tillage system (Raimundo, 2003).

High nutrient release was observed (60, 67, 57, 65 and $46 \%$ for $\mathrm{N}, \mathrm{P}, \mathrm{K}, \mathrm{Ca}$ and $\mathrm{Mg}$, respectively) for the leaf litter and burs buried in the soil, at the end of the incubation period (Fig. 5). As mass loss under the conventional soil tillage conditions (that is, intensive soil disturbance) was enhanced, it is expected that those nutrients were largely released during the period correspondent to that of the decomposition experiment.

Despite differences observed in the residue decomposition rate, nutrient dynamics during the first year of incubation was not affected by the residue placement (Fig. 5). However, in the remainder of the incubation period, the maintenance of leaf litter and burs on the soil surface led to a substantial decrease in the respective nutrient release. In fact, $\mathrm{N}$ release from these residues was not observed at the end of the decomposition experiment (2.25 years). Besides, the $\mathrm{P}, \mathrm{Ca}, \mathrm{Mg}$ and $\mathrm{S}$ amounts released from decomposing litter on the soil surface were only $36,23,20$ and $13 \%$ of the total, respectively. Consequently, high amounts of nutrients were accumulated in the organic layers. For example, after eight years, the amounts of $\mathrm{N}$ in these layers reached 249 and $106 \mathrm{~kg} \mathrm{ha}^{-1}$ under the tree crown and in the open area, respectively (Tab. IV), and those of Ca were 215 and $83 \mathrm{~kg} \mathrm{ha}^{-1}$, which agrees with the slow release of $\mathrm{N}$ and $\mathrm{Ca}$ from decomposing leaves and burs on the soil surface. In contrast to other nutrients, $\mathrm{K}$ release dynamics was not affected by the litter placement on the soil. However, its amount in the organic layers was also high (261-274 $\left.\mathrm{kg} \mathrm{ha}^{-1}\right)$, which may be related to the quantity of $\mathrm{K}$ in throughfall of chestnut stands (17.3 kg ha ${ }^{-1} \mathrm{y}^{-1}$ ) reported by Pires and Portela (2005), and to contamination by soil particles (micas) rich in this nutrient.

Beneath the tree crown, the annual retention of $\mathrm{N}$ in organic layers over eight years (about $31 \mathrm{~kg} \mathrm{ha}^{-1} \mathrm{y}^{-1}$, Tab. IV) was greater than the annual flux to the soil through leaf litter and burs $\left(24.5 \mathrm{~kg} \mathrm{ha}^{-1}\right.$, Fig. 5). Although fertilizer application may influence the amounts of $\mathrm{N}$ in the organic layers, its amount $\left(8.2 \mathrm{~kg} \mathrm{ha}^{-1} \mathrm{y}^{-1}\right)$ was too small to explain the great amount retained in the organic layers. Therefore, it means that the no-tillage system will contribute to retaining high amounts of $\mathrm{N}$ in organic layers, which are therefore not transferred to the mineral soil layers. Although data on composition and organic layers suggest a similar trend for $\mathrm{P}$ and $\mathrm{Ca}$, the respective amounts in the organic layers may be masked by their application as fertilizers (15.3 and $102.8 \mathrm{~kg} \mathrm{ha}^{-1} \mathrm{y}^{-1}$, respectively, for $\mathrm{P}$ and $\mathrm{Ca}$ ).

\subsection{Soil mineral layer changes}

After eight years, soil bulk density up to $10 \mathrm{~cm}$ depth was lower in the conventional than in the no-tillage system, but differences were not significant (Tab. V). This trend may be associated with the frequent tillage operations in the former during the year. Contrasting with the $5-10 \mathrm{~cm}$ soil layer, the $0-5 \mathrm{~cm}$ top soil layer of the no-tillage system showed higher contents of organic $\mathrm{C}, \mathrm{N}$, extractable $\mathrm{P}$ and exchangeable $\mathrm{Ca}$ and $\mathrm{Mg}$ (Tab. V) than in the conventional system, but significant differences were only observed for exchangeable $\mathrm{Ca}$. This pattern may be in relation to the direct interaction of decomposing residues (and fertilizers) with the top soil layer, suggesting that placement of chestnut residues on the soil surface created a stronger gradient of their content with soil depth. Despite the accumulation of nutrients in the organic layers, the no-tillage system enhanced their contents in the top soil layer. This agrees with results reported for lysimeter studies in Portugal with chestnut leaf litter (Raimundo et al., 2002) and several other species' leaf litters (Madeira and Ribeiro, 1995). The lower gradient of organic $\mathrm{C}$ and nutrient contents with soil depth in the conventional tillage system may be related to the mixture of decomposing residues and soil layers through tillage operations.

The results also suggest that the amount of organic $\mathrm{C}$ in the system increased through the no-tillage system use. In fact, the amount of organic $\mathrm{C}$ (taking into account bulk density values and organic C content, Tab. V) down to $20 \mathrm{~cm}$ soil depth was $6.44 \mathrm{~kg} \mathrm{~m}^{-2}$ in the conventional tillage system (see Tab. V), while in the no-tillage system it was $7.60 \mathrm{~kg} \mathrm{~m}^{-2}$. The amount in the latter was larger $\left(8.29 \mathrm{~kg} \mathrm{~m}^{-2}\right)$ if the amount in the organic layers was considered. That is, in the no-tillage system the accumulation of organic $\mathrm{C}$ may have occurred through the buildup of organic layers and the protection of soil organic 
Table V. Bulk density (BD) and soil chemical characteristics over an eight-year period in conventional tillage (CT) and no-tillage (NT) plots.

\begin{tabular}{|c|c|c|c|c|c|c|c|c|c|c|}
\hline Treat & $\begin{array}{c}\mathrm{BD} \\
\left(\mathrm{g} \mathrm{cm}^{-3}\right)\end{array}$ & \multicolumn{2}{|c|}{$\begin{array}{cc}\text { Org C } & \text { N } \\
\left(\mathrm{g} \mathrm{kg}^{-1}\right) & \\
\end{array}$} & $\bar{P}$ & $\mathrm{~K}$ & $\begin{array}{c}\mathrm{pH} \\
\left(\mathrm{H}_{2} \mathrm{O}\right) \\
\end{array}$ & \multicolumn{4}{|c|}{ Exchangeable cations $\left(\mathrm{cmol}_{c} \mathrm{~kg}^{-1}\right)$} \\
\hline $\mathrm{CT}$ & 1.15 & 39.4 & 2.19 & 122.2 & 263.3 & 5.6 & $2.44 \mathrm{~b}$ & 0.61 & 0.66 & 0.26 \\
\hline \multicolumn{11}{|c|}{$5-10 \mathrm{~cm}$} \\
\hline $\mathrm{CT}$ & 1.15 & 28.6 & 1.68 & 98.7 & 183.6 & 5.4 & 1.85 & 0.44 & 0.47 & 0.47 \\
\hline NT & 1.30 & 27.3 & 1.44 & 58.3 & 150.6 & 5.3 & 1.22 & 0.30 & 0.39 & 0.55 \\
\hline NT & 1.32 & 19.9 & 1.33 & 15.8 & 101.9 & 5.0 & 0.46 & 0.19 & 0.25 & 1.00 \\
\hline
\end{tabular}

* Except for $\mathrm{Ca}$ in the $0-5 \mathrm{~cm}$ layer, differences were not significant $(p>0.05)$ between treatments, by Tukey HSD multiple comparison tests.
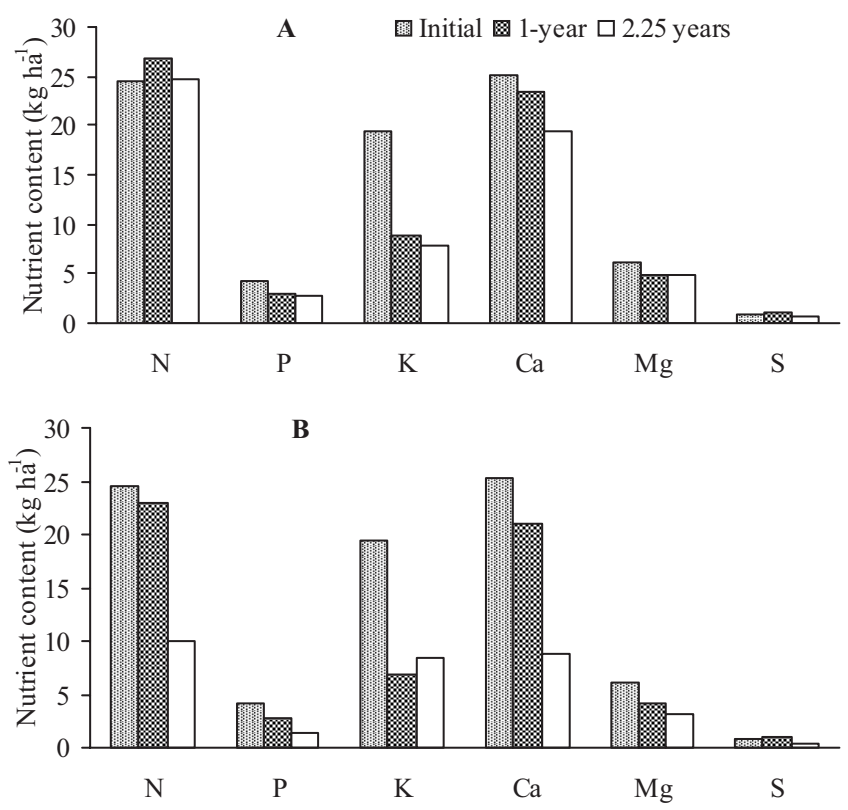

Figure 5. Nutrient content $\left(\mathrm{kg} \mathrm{ha}^{-1}\right)$ in the initial mass of leaves and burs and in decomposing leaves and burs 1-year and 2.25 years, placed on surface (A) or buried into the soil (B).

matter due to absence of tillage operations. This agrees with results of long-term studies reported by Diekow et al. (2005) and Heenan et al. (2004), where a positive influence of notillage (with residue placement on the soil surface) on preservation of soil organic matter was observed, whereas tillage promotes the mineralization of plant residues and the reduction of organic matter in the soil. Therefore, the no-tillage system in the chestnut stands may provide a means to enhance $\mathrm{C}$ sequestration in the soil.

Despite the accumulation of $\mathrm{N}$ in the organic layers $(0.025$ $\mathrm{kg} \mathrm{m}^{-2}$, Tab. V), the amount of $\mathrm{N}$ in the no-tillage system down to $20 \mathrm{~cm}$ depth $\left(0.455 \mathrm{~kg} \mathrm{~m}^{-2}\right)$ (only mineral layers) was greater than in the conventional tillage system $\left(0.381 \mathrm{~kg} \mathrm{~m}^{-2}\right)$ (see Tab. V). This is in line with data for organic $\mathrm{C}$ and may be associated with the effect of tillage operations on the organic matter mineralization. Despite those differences, the amounts of soil $\mathrm{N}$ mineralized in situ in the conventional tillage and in the no-tillage system were of the same magnitude, and similar results were obtained in incubations under controlled conditions (Raimundo et al., 2004). This is in agreement with the fact that tree nutrition and productivity during the study (Raimundo, 2003; Raimundo et al., 2001) were not affected by replacing the conventional system by the no-tillage system.

\section{CONCLUSIONS}

The replacement of the conventional soil tillage by the notillage system affected the decomposition rate and nutrient release dynamics of leaves and burs, as decomposition of litter placed on the soil surface and nutrient release was slower than that buried in the soil. The no-tillage system in chestnut stands will lead to the buildup of floor litter layers, and therefore to the retention of nutrients on the soil surface, especially for $\mathrm{N}$ and $\mathrm{Ca}$. This reduces the amount of nutrients returned through litter decomposition to the mineral soil, in the first years of the new system. However, after eight years, contents of organic C, $\mathrm{N}$, exchangeable $\mathrm{Ca}$ and $\mathrm{Mg}$, and extractable $\mathrm{P}$, in the $0-5 \mathrm{~cm}$ soil layer, were greater in the no-tillage than in the conventional tillage system, but differences were only significant for $\mathrm{Ca}$. The no-tillage system may enhance the accumulation of organic $\mathrm{C}$ in both organic and mineral soil layers due to the absence of tillage operations. The results also suggest that the no-tillage system will enhance soil quality as compared with conventional tillage.

Acknowledgements: The study was carried out within the activities of the projects PAMAF 4029 and PRAXIS, 3/3.2/FLOR/2123/95. Thanks are due to Mr. João Xavier and Dr. Osório Araújo for the availability of chestnut stands to install the experimental system. Thanks are also due to Professor João Coutinho for analytical support in the Soil Laboratory of the Trás-os-Montes e Alto Douro University, and to J. Pinheiro for fieldwork assistance.

\section{REFERENCES}

Azevedo A., Madeira M., Hilário L., and Marques P., 2004. Fertilidade de solos afectados por práticas de silvicultura intensiva. 1. Efeitos da gestão dos resíduos de abate e da sua composição química nas dinâmicas do C e do N. Revista de Ciências Agrárias 27: 329-346. 
Beare M.H., Parmelee R.W., Hendrix P.F., Cheng W., Coleman D.C., and Crossley D.A., 1992. Microbial and faunal interactions and effects on litter nitrogen and decomposition in agroecosystems. Ecol. Monogr. 62: 569-591.

Buchanan M., and King L.D., 1993. Carbon and phosphorus losses from decomposing crop residues in no-till and conventional till agroecosystems. Agron. J. 85: 631-638.

Costa J.C., Aguiar C., Capelo J.H., Lousã M., and Neto C., 1998. Biogeografia de Portugal Continental. Quercetea 0: 5-56.

Diekow J., Mielniczuk J., Knicker H., Bayer C., Dick D.P., and KögelKnabner I., 2005. Soil C and N stocks as affected by cropping systems and nitrogen fertilisation in a southern Brazil Acrisol managed under no-tillage for 17 years. Soil Till. Res. 81: 87-95.

Douglas C.L., Alimaras R.R., Rasmussen P.E., Raming R.E., and Roager N.C., 1980. Wheat straw composition and placement effects on decomposition in dryland agriculture of the Pacific Northwest. Soil Sci. Soc. Am. J. 44: 833-837.

Effland M.J., 1977. Modified procedure to determine acid-insoluble lignin in the wood and pulp. Tappi 60: 143-144.

Elliott L.F. and Stott D.E., 1997. Influence of no-till cropping systems on microbial relationships. Adv. Agron. 60: 121-147.

Frey S.D., Elliott E.T., Paustian K., and Peterson G.A., 2000. Fungal translocation as a mechanism for soil nitrogen inputs to surface residue decomposition in a no-tillage agroecosystem, Soil Biol. Biochem. 32: 689-698.

Gallardo-Lancho J.F., Egido J.A., Gonzalez M.I., Rico M., Regina I.R., Gallego H., Martin A., Menendez I., Moreno G., Schneider K., Turrion B., and Saavedra J.,1995. Nutrient cycles in chestnut ecosystems of Sierra da Gata (Western-Central Spain). In: Romane F. (Ed.), Sustainability of Mediterranean ecosystems. Case study of the chestnut forest, Ecosystems Research Report 19, European Commission, pp. 23-44.

Gregorich E.G. and Ellert B.H., 1994. Decomposition of plant residues in soil under different management. Proceedings of 13th International Conference of the Soil Tillage for Crop Production and Protection of the Environment, Aalborg, Denmark, Vol. I. pp. 13-18.

Harmon M.E., Baker G.A., Spycher G., and Greene S.E., 1990. Leaf litter decomposition in the Picea/Tsuga forests. For. Ecol. Manage. 31: $55-66$.

Heenan D.P., Chan K.Y., and Knight P.G., 2004. Long-term impact of rotation, tillage and stubble management on the loss of soil organic carbon and nitrogen from a Chromic Luvisol. Soil Till. Res. 76: 59-68.

Holland E.A. and Coleman D.C., 1987. Litter placement effects on microbial and organic matter dynamics in an agroecosystems. Ecology 68: $425-433$.

Holland J.M., 2004. The environmental consequences of adopting conservation tillage in Europe: reviewing the evidence. Agric. Ecosyst. Environ. 103: 1-25.

INE, 2005. Estatísticas agrícolas 2004, Instituto Nacional de Estatística, Lisboa.

Instituto de Meteorologia, 2007. Normais climáticas do período de 1961 a 1990, Bragança, http://www.meteo.pt/resources/im/pdfs/ clim_ac_61_90_Braganca.pdf.

Joergensen R.G. and Meyer B., 1990. Nutrient changes in decomposing beech leaf litter assessed using a solution flux approach. J. Soil Sci. 41: 279-293.

Jones H.E., Madeira M., Herraez L., Dighton J., Fabião A., Gonzalez-Rio F., Marcos M.F., Gomez C., Tomé M., Feith H., Magalhães M.C., and Howson G., 1999. The effect of organic-matter management on productivity of Eucalyptus globulus stands in Spain and Portugal: tree growth and harvest residue decomposition in relation to site and treatment. For. Ecol. Manage. 122: 73-86.
Kumar K. and Goh K.M., 2000. Crop residues and management practices: effects on soil quality, soil nitrogen dynamics, crop yield, and nitrogen recovery. Adv. Agron. 68: 197-319.

Lal R., 1994. Sustainable land use systems and soil resilience. In: Greenland D.J. and Szabolcs I. (Eds.), Soil Resilience and Sustainable Land Use, CAB International, London, pp. 41-69.

Lousier J.D. and Parkinson D., 1978. Chemical element dynamics in decomposing leaf litter. Can. J. Bot. 56 2795-2812.

Madeira M. and Ribeiro C., 1995. Influence of leaf litter type on the chemical evolution of a soil parent material (sandstone). Biogeochemistry 29: 43-58.

Marschner A., 1995. Mineral nutrition of higher plants, Academic Press, London.

Martins A., Azevedo S., Raimundo F., Carvalho L., and Madeira M., 2008. Decomposição de folhada de quatro espécies florestais no Norte de Portugal: Taxa de decomposição e evolução da composição estrutural e do teor em nutrientes. Revista de Ciências Agrárias (in press).

Olson T.S., 1963. Energy storage and the balance of producers and consumers in ecological systems. Ecology 44: 322-331.

Pereira E., 2004. Influência do freixo no microclima, nas características do solo e disponibilidade de nutrientes, e na vegetação herbácea de lameiros do Noroeste de Portugal. Ph. D. thesis, Instituto Superior de Agronomia, Universidade Técnica de Lisboa, Lisboa.

Pires A.L. and Portela E., 2005. Impact of management practices on chestnut grove nutrient budgets. Acta Hortic. 693: 677-684.

Portela E., Aranha J., Martins A., and Pires A.L., 1999. Soil factors, farmer's practices and chestnut ink disease: some interactions. Acta Hortic. 494: 433-441.

Raimundo F., 2003. Sistemas de mobilização do solo em soutos. Influência na produtividade de castanha e nas características físicas e químicas do solo, Ph.D. thesis, Universidade de Trás-os-Montes e Alto Douro, Vila Real.

Raimundo F., Branco I., Martins A., and Madeira M., 2001. Efeito da intensidade de preparação do solo na biomassa radical, regime hídrico, potencial hídrico foliar e produção de castanha de soutos do Nordeste Transmontano. Revista de Ciências Agrárias 24: 415-423.

Raimundo F., Madeira M., Coutinho J., and Martins A., 2002. Simulação lisimétrica da gestão da folhada de Castanea sativa. Efeito na lixiviação de nutrientes e nas características químicas do solo. Revista de Ciências Agrárias 25: 101-119.

Raimundo F., Madeira M., Coutinho J., and Martins A., 2004. Efeito de sistemas de mobilização do solo na mineralização do $\mathrm{N}$, na biomassa microbiana e na respiração do solo de soutos do Nordeste de Portugal. Revista de Ciências Agrárias 27: 361-375.

Ribeiro C., Madeira M., and Araújo M.C., 2002. Decomposition and nutrient release from leaf litter of Eucalyptus globulus grown under different water and nutrient regimes. For. Ecol. Manag. 171: 31-41.

Ricardo C.P. and Teixeira A.N. 1997. Moléculas biológicas. Estrutura e propriedades, Didáctica Editora, Lisboa.

Sá C., 2001. Influência do coberto arbóreo (Quercus suber L.) em processos ecofisiológicos da vegetação herbácea em áreas de montado, $\mathrm{Ph} . \mathrm{D}$. thesis, Universidade de Évora, Évora.

Sá C., Madeira M., and Gazarini L. 2005. Produção e decomposição de folhas de Quercus suber L. e Q. rotundifolia Lam. Revista de Ciências Agrárias 28: 257-272.

Santa-Regina I., San-Miguel C., and Gallardo J.F., 1986. Evolución y velocidad de descomposición de la hojarasca en tres bosques en la Sierra de Béjar (Salamanca). Anuario do Centro de Edafologia e Biología Aplicada 11: 217-231. 
Schomberg H.H., Steiner J., and Unger P.W., 1994. Decomposition and nitrogen dynamics of crop residues: residue quality and water effects. Soil Sci. Soc. Am. J. 58: 372-381.

Staaf H. and Berg B., 1982. Accumulation and release of plant nutrients in decomposing Scots pine litter: long-term decomposition in Scots pine forest II. Can. J. Bot. 60: 1561-1568.

Stevenson F.J., 1986. Cycles of Soil; carbon, nitrogen, phosphorus, sulphur, micronutrients, Wiley, New York.

Tutua S.S., Goh K.M., and Daly M.J., 2002. Decomposition and nitrogen release of understorey plant residues in biological and integrated apple orchards under field conditions in New Zealand. Biol. Fertil. Soils 35: 277-287.
Wardle D.A., 1995. Impact of disturbance on detritus food-webs in agroecosystems of contrasting tillage and weed management practices. Adv. Ecol. Res. 26: 105-185.

Wesemael B., 1993. Litter decomposition and nutrient distribution in humus profiles in some Mediterranean forests in southern Tuscany. For. Ecol. Manage. 57: 99-114.

Wieder R.K. and Lang G.E., 1982. A critique of the analytical methods used in examining decomposition data obtained from litter bags. Ecology 63: 1636-1642.

WRB, 2006. (IUSS Working Group WRB), World reference base for soil resources, 2nd edition, World Soil Resources Reports 103, FAO, Rome. 